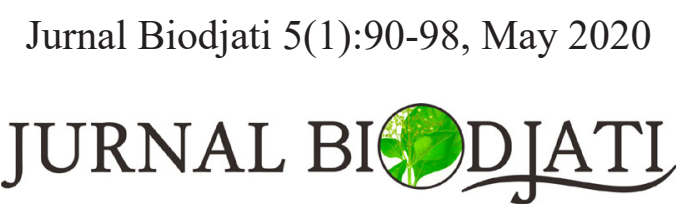

e-ISSN : 2541-4208

p-ISSN : 2548-1606

http://journal.uinsgd.ac.id/index.php/biodjati

\title{
A NOTE ON THE GENUS Evolvulus (CONVOLVULACEAE) IN JAVA, INDONESIA
}

\section{Arifin Surya Dwipa Irsyam ${ }^{1 *}$, Muhammad Rifqi Hariri², Rina Ratnasih Irwanto ${ }^{3}$, Wendy Achmmad Mustaqim ${ }^{4}$}

Received : January 27, 2020

Accepted : May 03, 2020

DOI: 10.15575/biodjati.v5i1.7502

${ }^{1}$ Herbarium Bandungense (FIPIA), School of Life Sciences and Technology (SITH), Institut Teknologi

Bandung, Labtek VC Building, Jatinangor, Jawa Barat, Sumedang

${ }^{2}$ Center for Plant Conservation, Bogor

Botanical Garden, Indonesian Institute of Sciences (LIPI), J1. Ir. H. Juanda 13, Bogor, West Java

${ }^{3}$ School of Life Sciences and Technology (SITH), Institut Teknologi Bandung, Labtek XI Building, Jl. Ganeca No. 10, Bandung, West Java ${ }^{4}$ Botany Division, Generasi Biologi

Indonesia (Genbinesia) Foundation, Keywords: Convolvulaceae, Evolvulus, exotic species, Java Jl. Swadaya Barat No. 4, Semampir, Cerme, Gresik, East Java
Abstract. According to the Flora of Java, there is only one species of Evolvulus in Java, namely Evolvulus alsinoides. Since then, a second species was reported in 2017 from Universitas Indonesia, Depok, West Java, as an alien naturalized species. Some recent field studies have been conducted to provide updated taxonomic information of the genus on this island. The field observations were carried out in Banten, Jakarta, West Java, Yogyakarta and East Java from March to December 2019. The herbarium studies were also conducted in Herbarium Bogoriense, Herbarium of Bogor Botanic Gardens, Herbarium Bandungense and Herbarium of the Department of Biology, Universitas Indonesia. Our study reveals one newly recorded species of Evolvulus in Java already grown in cultivation, namely E. glomeratus Nees \& Mart. subsp. grandiflorus (Parodi) Ooststr. Besides that, Evolvulus nummularius is now also reported to occur in other sites of West Java and extended to Central Java. An updated key of Evolvulus in Java, descriptions to both species, photographs and brief discussions are provided.

e-mail:

*1arifin@sith.itb.ac.id

²muhammad.rifai.hariri@lipi.go.id

rina@sith.itb.ac.id

4wendyachmmadm@gmail.com

*Corresponding author

\section{Citation}

Irsyam, A. S. D., Hariri, M. R., Irwanto, R. R. \& Mustaqin, W. A. (2020). A Note on the Genus Evolvulus (Convolvulaceae) in Java, Indonesia. Jurnal Biodjati, 5(1), 90-98.

\section{INTRODUCTION}

Evolvulus L. (Convolvulaceae) comprises as many as 100 species widely distributed in the Neotropics (van Oostroom, 1934; Junqueira \& Simão-Bianchini, 2006). Morphologically, the genus is characterized by its non-twining habit, unlobed leaves, the presence of two-branched trichomes, corolla with purple, blue or white color, two forked styles, filiform stigmas and glabrous seeds (Backer \& Bakhuizen van den Brink, 1965; Junqueira \& Simão-Bianchini, 2006; Staples, 2010; Simões et al., 2011). Two species of the genus, Evolvulus alsinoides (L.) L. and Evolvulus nummularius (L.) L., have been natural- 


\section{Jurnal Biodjati 5(1):90-98, May 2020 \\ JURNAL BI@DIATI}

http://journal.uinsgd.ac.id/index.php/biodjati

ized in the Old World (van Oostroom, 1934).

The taxonomical information on Evolvulus of Java was published by Backer \& Bakhuizen van den Brink (1965) and van Oostroom (1934; 1953). They recognized only one species of Evolvulus in Java, namely $E$. alsinoides. Since then, one alien species was recorded from Depok, namely E. nummularius (Nisyawati \& Mustaqim, 2017). Some recent field botanical explorations were made in some areas of Java which reveal that there is another species of Evolvulus already present in Java. A thorough examination of the herbarium and literature has shown that the species is E. glomerulatus Nees \& Mart. subsp. grandiflorus (Parodi) Ooststr. Therefore, there is a need to provide updated taxonomic data on the genus Evolvulus in Java as a part of the Alien Flora of Java treatment currently undertaken by the authors.

\section{MATERIALS AND METHODS}

The field study was conducted using the exploration method according to Rugayah et al. (2004) from March to December 2019. The plant materials were collected using van Balgooy's method (1987) from several urban localities in Banten (Serpong), Jakarta, West Java (Bandung, Bogor, Depok, Garut, Jatinangor, Pangandaran, Sukabumi), Yogyakarta (Bantul) and East Java (Bondowoso, Malang, Surabaya, Madura Island), i.e. campus areas, pedestrian paths, city parks and agritourism places. These explorations were conducted in urban areas because the spread of alien species often begins in urban ecosystems (Mayer et al., 2017). The plant materials were preserved and observed in Herbarium Bandungense (FIPIA), School of Life Sciences and Technology
(SITH), Institut Teknologi Bandung (ITB). Two herbarium studies have been carried out between 2016 and 2019. In August 2016, the first have been done in Herbarium of the Department of Biology, Faculty of Mathematics and Natural Sciences, Universitas Indonesia. Three years later, in August 2019, further examinations of herbarium have been done in Herbarium Bogoriense (BO), Herbarium of Bogor Botanic Gardens (KRB) and Herbarium Bandungense (FIPIA).

The collected Evolvulus specimens were identified by comparing the description of the specimens to the previously published literatures for Evolvulus (van Oostroom, 1934; van Oostroom \& Hoogland, 1953; Backer \& Bakhuizen van den Brink, 1965; Staples, 2010) and literatures for weeds and alien species in Java or Indonesia (Backer \& van Slooten, 1924; Everaarts, 1981; Soerjani et al., 1987; Setyawati et al., 2015; Tjitrosoedirdjo et al., 2016; Kementerian Pertanian, 2017; Nisyawati \& Mustaqim, 2017).

\section{RESULTS AND DISCUSSION}

A total of ten specimens of Evolvulus were collected from our recent explorations. Four of them belong to E. nummularius, a species recorded for the first time in Java by Nisyawati \& Mustaqim (2017). The other six were identified as E. glomeratus Nees $\&$ Mart. subsp. grandiflorus (Parodi) Ooststr. (Figure 1). The latter Specimens were collected from West Java (Bandung and Bogor) and East Java (Bondowoso and Malang) (Figure 1). No addition to the specimens of E. alsinoides, only one species recorded from the island before present publication. 


\section{Jurnal Biodjati 5(1):90-98, May 2020 \\ JURNAL BI@DIATI}

http://journal.uinsgd.ac.id/index.php/biodjati

An updated key to the Evolvulus species in Java

1. A. Leaves orbicular, base cordate, glabrous above; sepal ovate; corolla white

Evolvulus nummularius

B. Leaves otherwise, base acute to rounded, hairy above; sepal lanceolate; corolla blue

2 A. Peduncle up to $3 \mathrm{~cm}$; petiole up to $2 \mathrm{~mm}$ long.

Evolvulus alsinoides

B. Peduncle very short or absent; petiole $2 \mathrm{~mm}$ or longer

Evolvulus glomeratus subsp. grandiflorus

Evolvulus glomeratus Nees \& Mart. subsp. grandiflorus (Parodi) Ooststr., Meded. Bot. Mus. Herb. Rijks. Utrecht 14: 232 (1934).

Herb, perennial, prostrate or ascending and stem woody at the base. Stems reddish-brown, with a dense indumentum of white villose or villose-tomentose hairs, appressed. Leaves alternate, oblong, elliptic-oblong or obovate, $16-29 \times 8-14 \mathrm{~mm}$, base acute to rounded, margins entire, apex obtuse, triplinerved at the base, adaxial surface sericeous, green, abaxial surface covered by white hairs; petiole 2-4 mm long. Flowers solitary in the axils of leaves or aggregated into a terminal capitulum, sessile. Sepals free, 5, linear-lanceolate, $7 \mathrm{~mm}$ long, green, villose and ciliate. Corolla salverform, plicate, blue or lilac, white at the centre, tube $5 \mathrm{~mm}$ long, limb 5-lobed, up to 25 $\mathrm{mm}$ in diameter. Stamens 5, exserted, adnate to the corolla tube; filaments white, filiform, 5 $\mathrm{mm}$ long; anthers oblong, white, $2 \mathrm{~mm}$, dorsifixed. Ovary superior, ovoid, yellowish-green. Styles 2, each 2-branched; stigma 2, filiform, white, $12 \mathrm{~mm}$. Fruits and seeds unknown.

\section{Distribution}

Southern Brazil, Bolivia, Paraguay, Uruguay, to North Eastern Argentina (van Ooststroom, 1934). Introduced as cultivated species in Malaysia, Singapore (Chen et al., 2015) and Java.

\section{Habitat}

It is usually planted in open areas, shady areas and roadsides.

\section{Notes}

Evolvulus glomeratus subsp. grandiflorus is native to Tropical America (van Ooststroom, 1934). The species has been widely cultivated as an ornamental due to its beautiful blue-lilac flowers (Staples, 2008; Staples, 2010). The species has also been commonly grown as ornamental in some regions surrounding Indonesia, including Singapore, Thailand and Taiwan (Chen, 2007; Staples, 2008; Chen et al., 2015; Ketjarun et al., 2016). Based on an examination of material in BO, KRB and FIPIA, Evolvulus glomeratus subsp. grandiflorus has not previously been recorded in Java. We found that this species already cultivated in Java as an ornamental plant, but the information about when it was introduced in Java is uncertain. There is no record that the species has escaped from cultivation and become naturalized.

\section{Specimens Examined}

West Java: Cibeunying Park, Bandung, 07 March 2019, ASD Irsyam 212 (FIPIA); near the West Ceremonial Hall of Bandung Institut of Technology, Bandung, Jl. Ganesha No. 10, 08 July 2019, ASD Irsyam 280 (FIPIA); Bandung, J1. Riau, 08 July 2019, ASD Irsyam 281 (FIPIA); Jl. Raya Bogor, Cibinong, 08 August 2019, ASD Irsyam 282 (FIPIA).

East Java: Bondowoso, 03 March 2019, MR Hariri 41 (FIPIA); Kota Batu, Malang, 03 March 2019, MR Hariri 42 (FIPIA). 


\section{JURNAL BIDDJATI}

http://journal.uinsgd.ac.id/index.php/biodjati

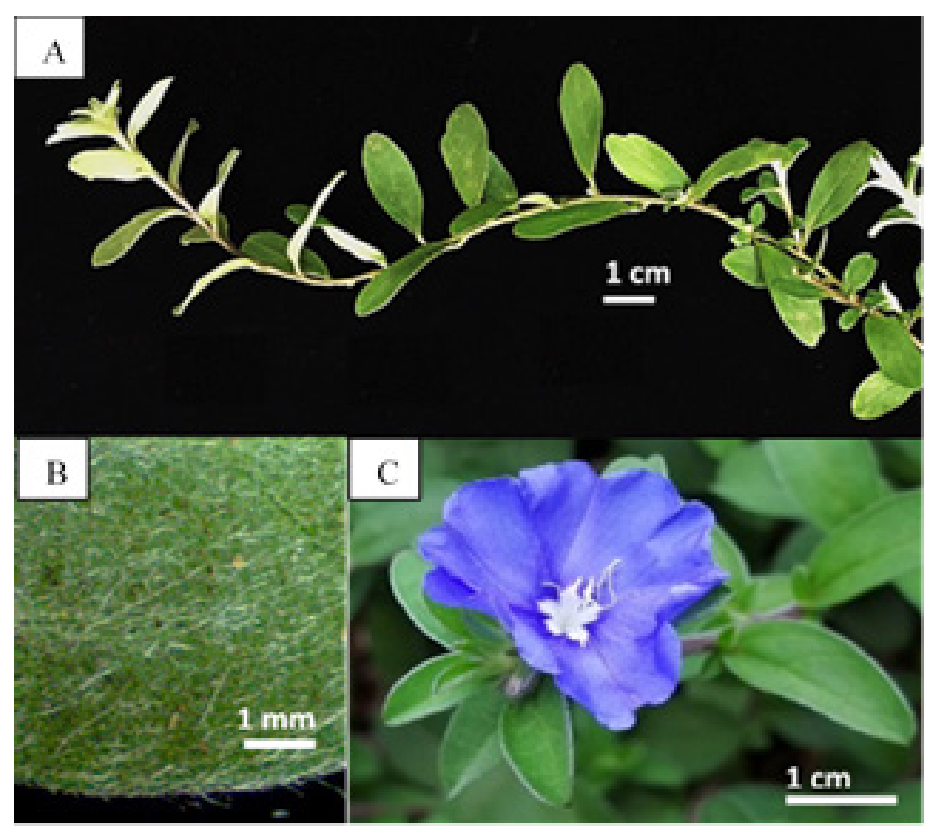

Figure 1. Evolvulus glomeratus Nees \& Mart. subsp. grandiflorus (Parodi) Ooststr. (A) habit, (B) hairs on the abaxial leaf surface, (C) flower

Evolvulus nummularius (L.) L., Sp. Pl. (ed. 2) 1: 391 (1762).

Herb, perennial, prostrate, pubescent. Stems slender, brown, villous or scabrous, rooting at nodes. Leaves distichous; orbicular to orbicular-obovate, $1.3-1.7 \times 1.2-1.4 \mathrm{~cm}$, base cordate to rounded, apex rounded or emarginate; glabrous or appressed pilose abaxially, rarely sparsely pubescent beneath; lateral veins 2 or 3 pairs; petiole $2-4 \mathrm{~mm}$. Flowers axillary, 1 or 2 per leaf axil, peduncles up to $5 \mathrm{~mm}$ long. Sepals persistent, oblong-ovate to oblong, 3-4× 2-3 mm, outer 2 sepals slightly longer than the inner sepals, pilose abaxially, margin ciliate. Corolla white, broadly campanulate or nearly salverform, ca. $6 \mathrm{~mm}$ wide; limb ca. 7-8 $\mathrm{mm}$ in diam., 5-lobed. Stamens 5, inserted at middle of corolla tube; filaments ca. $1.5 \mathrm{~mm}$ long, glabrous basally; anthers oblong. The ovary is superior, globose. Styles 2, lobes linear, ca. $3 \mathrm{~mm}$; stigma 2, minutely capitate. Fruits ovoid capsule, 2-3 mm in diam. Seeds 2-4 per fruit, brown to black, shiny, ovoid-trigoIrsyam et al. nous, ca. $1 \times 0.5 \mathrm{~mm}$, minutely tuberculate. Distribution

This species is native to Continental America from Mexico to N. Argentina, West Indies; tropical Africa, Madagascar: British India (Van Ooststroom, 1934; van Steenis, 1953).

Habitat. The species grows on open areas, gaps area between paving blocks or stones, and along the footpath at BBG, Universitas Indonesia (UI) and National Nuclear Energy Agency of Indonesia (BATAN).

\section{Specimens Examined}

Special Capital Region of Jakarta: research garden of BATAN, Pasar Jumat, 20 June 2019, MR Hariri 40 (FIPIA). West Java: Bogor Botanic Gardens, Bogor, 20 March 2019, MR Hariri 21-22 (FIPIA); Universitas Indonesia, Depok, 2015, WA Mustaqim 1217 (UI). Central Java: Wonogiri Regency, near the city center and settlement at near limestone hill, 28 September 2015, WA Mustaqim 1363 (UI); Wonogiri Regency, Jatisrono, open fields, 28 September 2015, WA Mustaqim 1368 (UI). 


\section{JURNAL BIDDJATI}

http://journal.uinsgd.ac.id/index.php/biodjati

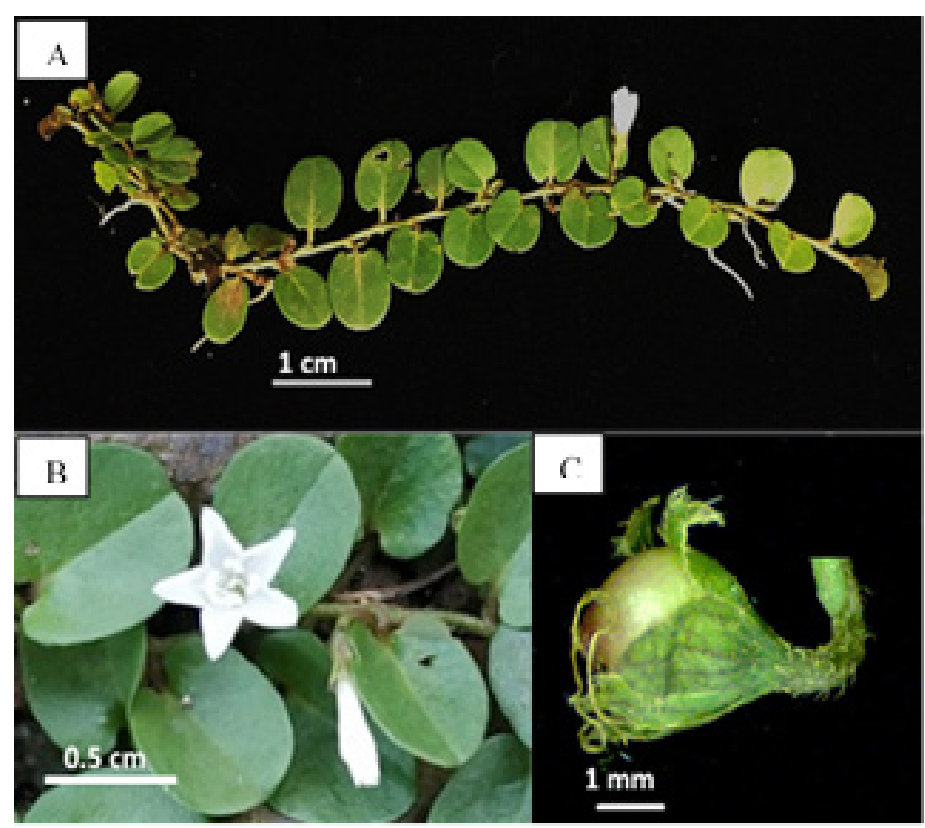

Figure 2. Evolvulus nummularius (L.) L. (A) habit, (B) flowers, (C) fruit

Evolvulus nummularius is distributed from Central to South America and it has just been recently recorded in Java. Although there is no clear evidence, there is a possibility that it was accidentally introduced to Java as a soil contaminant. Previous studies showed that some small-seeded alien species were unintentionally introduced into Java as a contaminant, such as Erechtites valerianifolia (Link ex Wolf) Less. ex DC. and Praxelis clematidea (Griseb.) R.M.King \& H.Rob. (Tjitrosoedirdjo et al., 2016; Tjitrosoedirdjo \& Wahyuni, 2018). Evolvulus nummularius was collected for the first time from Wonogiri Regency, Central Java, in September 2015, but this information still not published elsewhere until now. Later, the species has been previously reported from Depok (Nisyawati \& Mustaqim, 2017) and Jakarta (Mustaqim et al., 2019). In this study, the species was also collected from Bogor Botanical Gardens (BBG) and the National Nuclear Energy Agency of Indonesia (BATAN), Jakarta. It is now concluded that this species has been Jurnal Biodjati 5(1):90-98, May 2020 found in two of three main phytogeographical regions of Java, a quite significant geographic extension from the previous publication by Niswayati \& Mustaqim (2017).

There is no record on the intended introduction of E. nummularius according to our examination in many previous publications (Blume, 1823; Binnendijk \& Teysmann, 1855; Boerlage, 1901; Boldingh, 1914; Danimihardja \& Notodihardjo, 1978; Danimihardja \& Notodihardjo, 1985; Astuti et al., 2001; Sari et al., 2010; Nisyawati \& Mustaqim, 2017; Ariati et al., 2019). Therefore, we concluded that the presence of this species in BBG was not made by the human. Evolvulus nummularius is a small-seeded species, and the seeds are possibly dispersed by wind, water and ectozoochory, i.e. by transported on human feet at BBG. Lakshminarayana \& Raju (2017) reported that the seeds of E. nummularius had been dispersed by wind and rainwater in India.

The pollination mechanism of E. nummularius in our research sites is not known. But, the previous study has suggested that the 


\section{Jurnal Biodjati 5(1):90-98, May 2020 \\ JURNAL BI@DIATI}

http://journal.uinsgd.ac.id/index.php/biodjati

pollinator of E. nummularius during a rainy season in India is a snail (Lamellaxis gracile), due to its flower position is located close to the ground surface (Sarma et al., 2007). Moreover, E. nummularius also produces nectars and pollinated by several species of bees (Apis cerana and Trigona iridipennis) or butterflies (Zizeeria karsandra, Zizina otis, Chilades laius, Chilades pandava and Euchrysops cnejus) (Lakshminarayana \& Raju, 2017).

Other than Indonesia, E. nummularius was also reported as a newly recorded alien species in Southern China, Singapore and Taiwan (Fang \& Staples, 1995; Chen et al., 2009; Chua, 2016). The further ranges of E. nummularius in Java after Nisyawati \& Mustaqim (2017) needs to be noticed, due to its potential as an invasive alien species. Moreover, it has been considered as invasive alien species in India and Vietnam (Tan et al., 2012; Desmukh et al., 2017). In India, the species has also been reported as a weed of agricultural fields (Naidu, 2012; Gaddeyya \& Kumar, 2014; Khobragade \& Sathawane, 2014; Kaur et al., 2018).

Evolvulus nummularius are traditionally used as Asian herbal medicine, especially in North-East India (Ketjarun et al., 2016; Saha et al., 2016). Previous pharmacological studies showed that $E$. nummularius has antibacterial, anthelmintic, antioxidant and wound healing activities (Dash et al., 2003; Saini et al., 2007; Pavithra et al., 2009; Saha et al., 2016). The methanol extract of $E$. nummularius is effective against Bacillus subtilis, Pseudomonas aeruginosa, Klebsiella pneumoniae and Escherichia coli (Pavithra et al., 2009). The presence of tannins, flavonoids and triterpenoids in the methanol extract might play an important role as antioxidant properties (Pavithra et al., 2009). Based on these studies, the species can be developed as a medicinal plant in Indonesia. On the other hand, the pharmacological studies of E. glomeratus subsp. grandiflorus are not provided yet and require further research.

Three species of Evolvulus (Convolvulaceae) are now recognized in Java. Evolvulus glomeratus Nees \& Mart. subsp. grandiflorus (Parodi) Ooststr. is a new record for Java which has been collected from Jakarta, West Java (Bandung and Bogor) and East Java (Bondowoso and Malang). Evolvulus nummularius, previously only known from West Java, is shown to have a much wider geographic range within Java. The results of our study suggested that the taxonomy of Convolvulaceae in Java needs to be updated to accommodate the species that have not been included in Flora of Java.

\section{ACKNOWLEDGEMENTS}

The authors would like to thank the Director of Herbarium Bogoriense (BO), Head of Department of Biology and herbarium staff, FMIPA, Universitas Indonesia. We would also like to give our thanks to Mr. David J. Middleton from Singapore Botanic Garden for his valuable comments and suggestions to the manuscript.

\section{REFERENCES}

Ariati, S. R., Astuti, R. S., Supriyatna, I., Yuswandi, A. Y., Setiawan, A., Saftaningsih, D. \& Pribadi, D. O. (2019). An Alphabetical List of Plant Species Cultivated in the Bogor Botanic Gardens. Bogor: Pusat Konservasi Tumbuhan Kebun Raya-LIPI.

Astuti, I. P., Soewilo, L. P., Said, T. D. \& Kosasih, R. N. A. (2001). An Alphabetical List of Plants Species Cultivated in the Bogor Botanical Garden. Bogor: CV. Riza Graha Jaya. 


\section{Jurnal Biodjati 5(1):90-98, May 2020 \\ JURNAL BI@DIATI}

http://journal.uinsgd.ac.id/index.php/biodjati

Backer, C. A. \& van Slooten, D. F. Jr. (1924). Geillustreerd Handboek der Javaansche Theeonkruiden en Hunne Betekenis voor de Cultuur. Batavia: Drukkerijen Ruygok \& Co.

Backer, C. A. \& Bakhuizen van den Brink, R. C. Jr. (1965). Flora of Java. Volume II. Groningen, The Netherlands: Wolters-Noordhoff N. V.

Binnendijk, S. \& Teysmann, J. E. (1855). Catalogus Plantarum Quae in Horto Botanico Bogoriensi Coluntur. Batavia: Lands-Drukkerij.

Blume, C. L. (1823). Catalogus van Eenige der Merkwaardigste Zoo in-Als uit-Heemsche Gewassen, te Vinden in's Lands Plantetuin te Buitenzorg. Batavia: Landsdrukkerij.

Boerlage, J. G. (1901). Catalogus Plantarum Phanerogamarum Quae in Horto Botanico Bogoriensi Coluntur Herbaceis Exceptis. Bataviae: Typis Officinae Publicae.

Boldingh, I. (1914). Catalogus Herbarii Plantarum in Horto Bogoriensi Cultarum. Bataviae: G. Kolff \& Co.

Chen, H. W. (2007) Pharmacognostical Studies on Evolvulus Species in Taiwan: (Evolvulus alsinoides and Evolvulus glomeratus). Master Thesis. Retrieved from China Medical University.

Chen, S. H., Su, J. Y. \& Wu, M. J. (2009). Notes on Two Newly Naturalized Plants in Taiwan: Evolvulus nummularius (L.) L. (Convolvulaceae) and Acalypha aristata Kunth (Euphorbiaceae). Taiwania, 54(3), 273-278.

Chen, L. M. J., Foong, A. W., Ng, A., Teo, J. \& YuRue, J. T. (2015). 1001 Garden Plants in Singapore, 3rd Edition. Singapore: National Parks Board.

Chua, K. S. (2016). New Record of the Creeping Plant Evolvulus nummularius in
Singapore. Singapore Biodiversity Records, 161.

Danimihardja, S. \& Notodihardjo, D. (1978). An Alphabetical List of Plant Species Cultivated in the Hortus Botanicus Bogoriensis. Bogor: Archipel.

Danimihardja, S. \& Notodihardjo, D. (1985). An Alphabetical List of Plant Species Cultivated in the Hortus Botanicus Bogoriensis. Bogor: Archipel.

Dash, G. K., Bijayini, M., Panda, A., Patro, C. P. \& Ganapaty, S. (2003). Anthelmintic Activity of Evolvulus nummularius. Indian Journal of Natural Products, 9(3), 24-26.

Desmukh, U. B., Reddy, E. S. \& Rathor, O. S. (2017). Invasive Alien Angiosperms Diversity from Bhiwapur Tahsil, Nagpur District of Vidharbha Region (M. S.), India. International Journal for Innovative Research in Multidisciplinary Field, 3(6), 434-441.

Everaarts, A. P. (1981). Weeds of Vegetables in The Highlands of Java. Jakarta: Lembaga Penelitian Hortikultura.

Fang, R. C. \& Staples, G. (1995). Convolvulaceae. In : Wu, Z. Y. \& Raven, P. H. (eds) Flora of China 16. Beijing, China and MBG, St. Louis, Missouri, USA: Science Press.

Gaddeyya, G. \& Kumar, P. K. R. 2014. Studies on Weed Infestation of Some Agricultural Fields at Visakhapatnam district, Andhra Pradesh. Journal of Crop and Weed, 10(2), 419-429.

Junqueira, M. E. R. \& Simão-Bianchini, R. (2006). O gênero Evolvulus L. (Convolvulaceae) no Município deMorro do Chapéu, BA, Brasil. Acta Botanica Brasilica, 20(1), 157-172.

Kaur, S., Barua, I. C., Kaur, T., Kaur, N., Kaul, A. \& Bhullar, M. S. (2018). Appearance of New Weeds in Punjab. Indian Jour- 


\section{Jurnal Biodjati 5(1):90-98, May 2020 \\ JURNAL BI@DIATI}

http://journal.uinsgd.ac.id/index.php/biodjati

nal of Weed Science, 50(1): 59-63.

Kementerian Pertanian. (2017). Deskripsi dan Visualisasi Jenis Asing Invasif (JAI) / Invasive Alien Species (IAS): Kelompok tumbuhan dan organisme yang berasosiasi dengan tumbuhan. Jakarta: Badan Karantina Pertanian Kementerian Pertanian.

Ketjarun, K., Staples, G. W., Swangpol, S. C. \& Traiperm, P. (2016). Micro-morphological Study of Evolvulus spp. (Convolvulaceae): the Old World Medicinal Plants. Botanical Studies, 57, 25.

Khobragade, D. P. \& Sathawane, K. N. (2014). Weed Diversity in Rabi Wheat Crop of Bhandara District (MS), India. International Journal of Life Sciences Special Issue A2, 128-131.

Lakshminarayana, G. \& Raju, A. J. S. (2017). Reproductive Biology and Ecology of Evolvulus alsinoides and Evolvulus nummularius (Convolvulaceae). Phytologia Balcanica, 23(3), 381-389.

Mayer, K., Haeuser, E., Dawson, W., Essel, F., Kreft, H., Pergl, J., Pyšek, P., Weigelt, P., Winter, M., Lenzner, B. \& van Kleunen, M. (2017). Naturalization of Ornamental Plant Species in Public Green Spaces and Private Gardens. Biological Invasions, 19(12), 3613-3627.

Mustaqim, W. A., Panggabean, I. P. D. R. \& Putrika, A. (2019). Flora Jakarta: Daftar Awal Jenis-Jenis Tumbuhan Berbiji. Gresik: Yayasan Generasi Biologi Indonesia.

Naidu, V. S. G. R. (2012). Hand Book on Weed Identification. Jabalpur, India: Directorate of Weed Science Research.

Nisyawati \& Mustaqim, W. A. (2017). A Field Guide to the Urban Plants of Universitas Indonesia. Jakarta: UI Press.

Pavithra, P. S., Sreevidya, N. \& Verma, R. S. (2009). Antibacterial and Antioxidant
Activity of Methanol Extract of Evolvulus nummularius. Indian Journal of Pharmacology, 41(5), 233-236.

Rugayah, Retnowati, A., Windadri, F. I. \& Hidayat, A. (2004). Pengumpulan Data Taksonomi. In: Rugayah, Widjaja, E. A. \& Praptiwi. Pedoman Pengumpulan Data Keanekaragaman Flora. Bogor: Puslit-LIPI.

Saha, S., Deb, B., Mullick, J. B., Choudhury, P. R., Saha, P., Ghosh, B. \& Sil, S. K. (2016). Antibacterial Activity of Evolvulus nummularius against Standard ATCC Gram Positive and Gram Negative Strains: Studies on MIC, MBC, Growth Curve Analysis and ROS Generation. International Journal of Pure \& Applied Bioscience, 4(4), 205-211.

Saini, V., Kinger, H. K., Sharma, D. K., Ahuja, N., Middha, A., Gupta, V. B. (2007). Wound Healing Activity of Evolvulus numularius Linn. Asian Journal of Chemistry, 19(7), 5772-5774.

Sari, R., Ruspandi \& Ariati, S. R. (2010). An Alphabetical List of Plant Species Cultivated in the Bogor Botanic Gardens. Bogor: Pusat Konservasi Tumbuhan Kebun Raya-LIPI.

Sarma, K., Tandon, R., Shivanna, K. R., \& Mohan Ram, H. Y. (2007). Snail-pollination in Volvulopsis nummularium. Current Science, 93(6), 826-831.

Setyawati, T., Narulita, S., Bahri, I. P. \& Raharjo, G. T. (2015). A Guide Book to Invasive Alien Plant Species in Indonesia. Bogor: Research, Development and Innovation Agency. Ministry of Environment and Forestry.

Simões, A. R., Silva, H. \& Silveira, P. (2011). The Convolvulaceae of Timor with Special Reference to East Timor. Blumea, 56(1), 49-72.

Staples, G. (2008). Curious about Convolvu- 


\section{Jurnal Biodjati 5(1):90-98, May 2020 \\ JURNAL BI@DIATI}

http://journal.uinsgd.ac.id/index.php/biodjati

laceae?. Gardenwise, 30, 6-8.

Staples, G. (2010). Convolvulaceae. In: Santisuk, T. \& Larsen, K. (eds) Flora of Thailand, vol. 10(3). Bangkok: Prachacohon.

Tan, D. T., Thu, P. Q. \& Dell, B. (2012). Invasive Plant Species in the National Parks of Vietnam. Forests, 3(4), 997-1016.

Tjitrosoedirdjo, S. S., Mawardi, I. \& Tjitrosoedirdjo, S. (2016). 75 Important Invasive Plant Species in Indonesia. Bogor: SEAMEO BIOTROP.

Tjitrosoedirdjo, S. S. \& Wahyuni, I. (2018). Rekor Baru Keberadaan Praxelis clematidea (Asteraceae) di Indonesia. In: Kurniadie, D., Widayat, D. \& Umiyati, U. (eds) Prosiding Seminar Nasional XX Himpunan Ilmu Gulma Indonesia: Resistensi Gulma terhadap Herbisida dan Dampaknya terhadap Lingkungan dan Produk Pertanian. Biotrop. van Balgooy, M.M.J. (1987). Collecting. In: de Vogel, E.F. (ed) Manual of Herbarium Taxonomy Theory and Practice. Jakarta: UNESCO.

van Steenis, C. G. G. J. (1958). Addenda, corrigenda et emendanda. In: van Steenis, C. G. G. J. (ed) Flora Malesiana Ser.1 Vol. 5(4). Jakarta: Noordhoff-Kolff N.V.

van Oostroom, S. J. (1934). A Monograph of the genus Evolvulus. Meded. Bot. Mus. Herb. Rijks Univ. Utrecht, 14, 1-267.

van Oostroom, S. J. \& Hoogland, R. D. (1953). Convolvulaceae. In: van Steenis, C. G. G. J. (ed) Flora Malesiana Ser.1 Vol. 4(4). Jakarta: Noordhoff-Kolff N.V. 